\title{
The Correlation Analysis of Capital Structure and Enterprise Value of Steel Industry’s Public Companies in China
}

\author{
Liang Qing \\ School of Economies and Management of Beijing Jiaotong University, Beijing, China \\ LiangQ89102@163.com
}

\begin{abstract}
This article selected the listed companies in iron and steel industry from Shanghai and Shenzhen A-share market to extract data from 2008 to 2012. Through the analysis of multivariate regression method, it analyzes the correlation of capital structure and enterprise value, and found the steel industry listed companies' capital structure influence on the enterprise value.

Index Terms - Capital structure, Enterprise value, Steel Industry, Multivariate regression analysis

\section{Introduction}

In recent economic situation, the development of China's steel industry is inseparable from the iron and steel enterprises to realize their own values. As a capital-intensive industry, the effective supply of funds is one of the necessary conditions to achieve the target value of steel companies. As a capitalintensive industry, the effective supply of funds is one of the necessary conditions to achieve the target value of steel companies. Under the new environmental and the challenges of international counterparts, in order to realize the growing enterprise value, the choice of the internal capital management method in China's steel industry is an urgent study. Therefore, It is of great significance to study and optimize the capital structure of China's steel enterprises from the most basic elements of business, which means capital, so as to enhance corporate value.
\end{abstract}

\section{Literature}

\section{A. Foreign Capital Structure Theory}

Modern capital structure theory originated in the MM theory. On the basis of MM theory with taxes, the trade-off theory took financial distress costs and off-set tax incomes into consideration. Based on balancing financial distress costs and off-set tax incomes, the trade-off theory emphasizes the optimal capital structure when enterprises maximize their value. Agency theory take debt agency costs and debt agency revenue into consideration on the basis of trade-off theory. According to Pecking order theory, the order of financing is internal financing, debt financing and equity financing.

Through the relevant theories about capital structure above, the correlation between capital structure and enterprise value Reflects in the following aspects. First of all, interest can reduce tax. So to some extent debt financing can increase enterprise value. Secondly, the cost of capital with liability is lower than the cost of capital without liability. Therefore, increasing the proportion of liability is conductive to reducing the weighted average cost of capital, which consequently enhances enterprise value. However, it is worth mentioning that the premise of the conclusion is that increasing the proportion of liability does not cause increase in the necessary return rate as creditor requires. In fact, increasing the proportion of liability will raise the risk of creditors and creditors will raise the necessary return rate, which results in increasing necessary return rate as equity investor require and may reduce enterprise value. Finally, liability financing will increase companies' bankruptcy costs and agency costs, resulting in the loss of enterprise value.

\section{B. Empirical Studies of Foreign Scholars}

Kester (1986) found a significant negative correlation between profitability and liability leverage by establishing a linear regression model with panel data from 344 Japanese companies and 425 U.S companies in 27 industries from 1982 to 1983.

An Empirical Study conducted by Booth (2001) et al. found a highly significant negative correlation between enterprise value in most developing countries and capital structure, through the analysis of the sample data from a dozen developing countries.

Frank and Goyal (2003) 's study use American nonfinancial enterprise database, collecting a huge data from 1950 to 2000 nearly 200,000 observed variables.

The empirical result shows a significantly positive correlation between enterprises performance and financial leverage ratio in book value and a significantly negative correlation between enterprises performance and financial leverage ratio in market value.

Brierley and Bun (2005)'s empirical research showed that the enterprise value had a positive correlation with financial leverage by collecting data from all listed companies in the UK from 1975 to 2004.

The empirical research results from foreign scholars show that different analysis methods and study objects end in different conclusions on the correlation between capital structure and enterprise value.

\section{Empirical Studies of Chinese Scholars}

Lu Zhengfei and Xin Yu (1998) 's study indicates that China's listed companies overall the liability ratio in China's public companies is high. and the profitability of the enterprise, which means the enterprise value at the same time is 
significantly negative correlated with debt ratio.

Feng Genfu, Wu Linjiang and Liu Shiyan (2000) proved a significant negative correlation among the market value of the enterprise, the debt ratio and short-term debt ratio

The research conducted by Xiao Zuoping had regression test by using TobinQ as a enterprise value indicator and collecting debt ratio and Tobin Q from 220 public companies before July 1st 1994.The regression result showed that debt ratio was negative correlated with enterprise value because of the soft constraints the state banks put on the state holding listed companies.

Chen Xiao and Shan Xin (1999) held the opinion that the enterprise value and capital structure had a positive correlation. Although the cost of equity in listed companies is lower than the cost of liability, liability financing can still reduce the companies' weighted average capital cost thus enhancing the market value.

To sum up, Chinese scholars did not reach the same conclusion, but most of them have adopted the empirical multivariate regression analysis. When selecting variables, domestic scholars mostly choose debt ratio on behalf of the capital structure and Tobin $\mathrm{Q}$ on behalf of the enterprise value, adding other control variables into their models. Throughout the research results of domestic scholars, the majority of those research based on the data samples from all listed companies, lacking of features based on industry analysis and interpretation. Therefore, on the basis of domestic and foreign scholars' research methods, this article selected listed companies in the steel industry as the analytical sample and explore the correlation between capital structure and enterprise value of public companies in steel industry.

\section{Empirical Analysis and Design}

\section{A. Sample Selection and Data Sources}

This paper selects the entire steel industry of China's Shanghai and Shenzhen A-share listed companies as sample companies to extract data from 2008 to 2012 to analyze the relevance between capital structure and corporate value. The number of sample companies is 29 . In order to ensure the validity of the data and eliminate the effects of abnormal factors on the findings, the paper screened the original sample according to the following criteria: (1) excluding ST and PT listed companies; (2) excluding the sample companies lack of necessary data; (3) excluding the sample companies with abnormal debt ratio. Finally, 135 groups of sample data were screened out for the study.

The data used in this paper are mainly from CSMAR databases. Data processing and analysis are measured primarily by Microsoft Excel software and SPSS19.0.

\section{B. Variables and Model}

\section{1) Variables}

Tobin $\mathrm{Q}$ is the most common measurable indicator of enterprise value and is used by most foreign literature. Tobin $\mathrm{Q}$ is a parameter proposed by economist Tobin to measure corporate performance. It is equal to the ratio of the company's market value to the replacement cost of the company's assets 。 The company's market value is equal to the market value of the company's stock plus the market value of bonds issued by the company.

Tobin $\mathrm{Q}=($ the market value of the company's circulation stock + the market value of preferred stock + the market value of bonds) / replacement cost of total assets.

In this paper, Tobin $\mathrm{Q}$ works as a measurable indicator of enterprise value. In order to better reflect the situation of China's listed companies, the paper makes the following adjustments to Tobin $\mathrm{Q}$.

First of all, before 2004, there are tradable shares and non-tradable shares in all listed companies in China. The tradable shares mainly circulates with private methods, such as negotiating transfer, auction, pledge and equity investment, by the end of 2004. Pricing of tradable shares is based on listed company's net asset value per share. Therefore, this paper believes that it's more objective to replace the market value of non-tradable shares by net asset value per share. Secondly, there is no preferred stock in capital markets in China, so this paper do not consider the market value of preferred stock. In addition, because of China's bond market is underdeveloped, in order to simplify the calculation, this paper uses the book value of liability instead of market value of liability. Finally, because the replacement value of total assets is difficult to get, the paper uses book value of total assets instead of the replacement value of the total assets

This paper chooses debt ratio as the measurable indicator. In order to control the impact of other factors on the enterprise value, considering the specificity of steel industry, this paper selects the company's profitability, operational capabilities and business growth as control variables. Table 1 shows the variables.

TABLE I Variables

\begin{tabular}{|c|c|c|c|}
\hline $\begin{array}{l}\text { Types of } \\
\text { Variables }\end{array}$ & $\begin{array}{l}\text { Variables } \\
\text { Name }\end{array}$ & Quantitative Index & $\begin{array}{l}\text { Variable } \\
\text { Symbol }\end{array}$ \\
\hline $\begin{array}{l}\text { Dependent } \\
\text { Variable }\end{array}$ & $\begin{array}{l}\text { Enterprise } \\
\text { Value }\end{array}$ & Tobin Q & Tobin $Q$ \\
\hline $\begin{array}{l}\text { Independent } \\
\text { Variable }\end{array}$ & $\begin{array}{l}\text { Capital } \\
\text { Structure }\end{array}$ & Debt Ratio & $X_{I}$ \\
\hline \multirow{3}{*}{$\begin{array}{c}\text { Control } \\
\text { Variables }\end{array}$} & Profitability & Net Profit on Total Assets & $X_{2}$ \\
\hline & $\begin{array}{l}\text { Operational } \\
\text { Capabilities }\end{array}$ & Total Assets Turnover & $X_{3}$ \\
\hline & $\begin{array}{l}\text { Business } \\
\text { Growth }\end{array}$ & $\begin{array}{l}\text { Increase Rate of Main } \\
\text { Business Revenue }\end{array}$ & $X_{4}$ \\
\hline
\end{tabular}

Where

Debt ratio $=$ the ending balance of total liability / the ending balance of total assets

Net profit on total assets $=$ net profit /average total assets Total assets turnover $=$ operating income $/$ average total assets Increase rate of main business revenue $=$ (operating income this year- operating income last year) / operating income last year 
2) Model

$$
\operatorname{Tc} \operatorname{bin} Q=\alpha+\beta_{1} X_{1}+\beta_{2} X_{2}+\beta_{3} X_{3}+\beta_{4} X_{4}+\varepsilon
$$

Where

$\alpha$ constant term

$\beta$ coefficient

$\varepsilon$ residual

\section{Hypotheses}

1) Hypotheses 1: There is a positive correlation between debt ratio and TobinQ. Hypotheses 1 is proposed on the basis of the following reasons. Firstly, according to MM theory with income tax, interest can reduce tax so liability financing can enhance the enterprise value. Secondly, according to Pecking order theory, liability financing can reduce the weighted average cost of capital thus enhancing enterprise value. Thirdly, liability financing requires companies to pay interest periodically, which is a constrain to a company and is in favor of enhancing enterprise value.

2) Hypotheses 2: Generally speaking, the stronger the companies' profitability is, the higher the enterprise value is .So as to A shares listed companies in China steel industry, this paper proposes hypotheses 2:there is a positive correlation between net profit on total assets and TobinQ.

3) Hypotheses 3: Stronger operation capacity means stronger ability to use assets to earn revenue, which can create enterprise value. So as to A shares listed companies in China steel industry, this paper proposes hypotheses 3: there is a positive correlation between total assets turnover and TobinQ.

4) Hypotheses 4: The higher the increase rate of main business revenue is, the greater potential the company has, resulting in higher enterprise value..So as to A shares listed companies in China steel industry, this paper proposes hypotheses 4 : there is a positive correlation between increase rate of main business revenue and TobinQ.

\section{Empirical Analysis}

\section{A. Descriptive Statistics}

Table 2 describes the feature of variables of sample companies. As the measurable indicator of enterprise value, the average Tobin $\mathrm{Q}$ is 1.15867 , greater than 1 , indicating that the average enterprise value of the A shares steel listed companies is greater. The maximum of TobinQ is 4.3980 and the minimum of TobinQ is 0.6875 and the standard deviation is 0.48099 , which indicates that the enterprise value in different companies vary a lot and measures of dispersion is great. As the measurable indicator of capital structure, the average debt ratio is 0.6355 , higher than the average debt ratio of the entire listed companies on A share market, which is 0.473. As a whole, listed companies in steel industry on A share market make a better use of liabilities. The maximum of debt ratio is 1.0181 and the minimum of debt ratio is 0.0954.The maximum and the minimum are different, which shows that different companies make the use of liabilities in different degrees.
TABLE II Descriptive Statistics

\begin{tabular}{|c|c|c|c|c|}
\hline Variables & $\begin{array}{c}\text { Minimu } \\
\mathrm{m}\end{array}$ & $\begin{array}{c}\text { Maximu } \\
\mathrm{m}\end{array}$ & Average & $\begin{array}{c}\text { Standard } \\
\text { Deviation }\end{array}$ \\
\hline TobinQ & 0.6875 & 4.3980 & 1.158665 & 0.4809915 \\
\hline Debt Ratio & 0.0954 & 1.0181 & 0.635458 & 0.1487453 \\
\hline $\begin{array}{c}\text { Net Profit on } \\
\text { Total Assets }\end{array}$ & -0.2603 & 0.3082 & 0.020590 & 0.0553314 \\
\hline $\begin{array}{c}\text { Total Assets } \\
\text { Turnover }\end{array}$ & 0.4203 & 3.3203 & 1.253502 & 0.5670870 \\
\hline $\begin{array}{c}\text { Increase Rate of } \\
\text { Main Business } \\
\text { Revenue }\end{array}$ & -0.7030 & 2.6052 & 0.128661 & 0.3640513 \\
\hline
\end{tabular}

\section{B. Empirical Results and Analysis}

Table 3 shows the goodness of fit of the model and Table 4 shows the analysis of variance. $\mathrm{R}$ square is 0.264 and adjusted $\mathrm{R}$ square is 0.241 , which means as a whole, independent variable and control variables can explain the change of dependent variable, so Derived from regression model fitting in good condition and meet the design requirements. DurbinWatson test result is 1.073 and close to 2, which means the regression residuals follow a normal distribution. There is no regression residuals autocorrelation phenomena, so this model is available. At a given significance level which is $0.01, \mathrm{~F}$ test value is 11.631 and much bigger than the critical value. The regression equation is significant from the perspective of statistical tests. In addition, At a given significance level which is 0.01 , the model passes the F test. There is a significant correlation between the independent variable and the dependent variable.

TABLE III Model Summary

\begin{tabular}{|c|c|c|c|c|}
\hline Model & $\mathrm{R}$ & R Square & Adjusted R Square & Durbin-Watson \\
\hline 1 & $0.513 \mathrm{a}$ & 0.264 & 0.241 & 1.073 \\
\hline
\end{tabular}

a Predictors: (Constant):, Net profit on total assets, Debt ratio, Increase rate of main business revenue, Total assets turnover

TABLE IV ANOVA

\begin{tabular}{|c|c|c|c|c|c|}
\hline Model & $\begin{array}{c}\text { Sum of } \\
\text { Square }\end{array}$ & $\mathrm{df}$ & $\begin{array}{c}\text { Mean } \\
\text { Square }\end{array}$ & $\mathrm{F}$ & Sig. \\
\hline Regression & 8.171 & 4 & 2.043 & $\begin{array}{c}11.63 \\
1\end{array}$ & $\begin{array}{c}0.000 \\
\mathrm{a}\end{array}$ \\
\hline Residual & 22.831 & 130 & 0.176 & & \\
\hline Total & 31.001 & 134 & & & \\
\hline
\end{tabular}

a Predictors: (Constant):, Net profit on total assets, Debt ratio, Increase rate of main business revenue, Total assets turnover

Table 5and Table 6 show the regression results and the univariable significance test result. VIF values of each variable are much less than 10 , indicating that there is no serious multicollinearity among the variables. At the significance level which is 0.01 , the debt ratio passes the $\mathrm{T}$ test and its 
coefficient is -0.920 .As a result, there is a significant negative correlation between debt ratio and TobinQ thus negating the hypothesis 1 . At the significance level which is 0.05 , the net profit on total assets passes the $T$ test and its coefficient is positive. So there is a significant positive correlation between net profit on total assets and TobinQ thus proving the hypothesis 2 . At the significance level which is 0.05 , the total assets turnover passes the $\mathrm{T}$ test and its coefficient is negative. As a result, there is a significant negative correlation between total assets turnover and TobinQ thus proving the hypothesis 3. Increase rate of main business revenue doesn't pass the $T$ test and what it can influence on TobinQ is still not sure, which cannot proves hypothesis 4 .

TABLE V Coefficients 1

\begin{tabular}{|l|c|c|c|c|c|}
\hline \multicolumn{1}{|c|}{ Model } & $\mathrm{B}$ & Standard Error & Beta & $\mathrm{t}$ & Sig. \\
\hline Constant & 1.878 & 0.243 & & 7.716 & $\begin{array}{c}0.00 \\
0\end{array}$ \\
\hline Debt ratio & -0.920 & 0.349 & -0.284 & -2.633 & $\begin{array}{c}0.01 \\
0\end{array}$ \\
\hline $\begin{array}{l}\text { Net profit on } \\
\text { Total Assets }\end{array}$ & 2.261 & 0.965 & 0.260 & 2.342 & $\begin{array}{c}0.02 \\
1\end{array}$ \\
\hline $\begin{array}{l}\text { Total Assets } \\
\text { Turnover }\end{array}$ & -0.138 & 0.066 & -0.162 & -2.085 & $\begin{array}{c}0.03 \\
9\end{array}$ \\
\hline $\begin{array}{l}\text { Increase Rate of } \\
\text { main Business } \\
\text { Revenue }\end{array}$ & -0.068 & 0.104 & -0.052 & -0.653 & $\begin{array}{c}0.51 \\
5\end{array}$ \\
\hline
\end{tabular}

TABLE VI Coefficients2

\begin{tabular}{|l|l|l|}
\hline \multirow{2}{*}{ Model } & \multicolumn{2}{|l|}{ Collinearity Statistics } \\
\cline { 2 - 3 } & Tolerance & VIF \\
\hline Constant & & \\
\hline Debt ratio & 0.485 & 2.061 \\
\hline Net Profit on Total Assets & 0.459 & 2.177 \\
\hline Total Assets turnover & 0.934 & 1.070 \\
\hline Increase Rate of main Business Revenue & 0.909 & 1.100 \\
\hline
\end{tabular}

\section{Conclusions}

\section{A. Correlation between Debt Ratio and TobinQ}

The final analysis conclusion there is a significant negative correlation between the debt ratio of $\mathrm{A}$ share listed companies in steel industry and enterprise value, which is contrary to the original hypothesis.

Liability financing has negative effects on enterprise value of companies in steel industry, the reason of which may be as follows.
First of all, creditors will increase the cost of business operation through a number of restrictive clauses. When companies in steel industry obtain liability financing, they must accept some restrictive provisions, such as minimum capital flows, capital flows restraint requirements, which will increase the costs of business operation.

Secondly, liability financing impacts on the investment decision of the steel industry companies by resulting in losing investment opportunities. Liability financing generally have fixed terms of repayment and maturity must service the debt on the maturity date, which requires iron and steel companies think more about projects with low income and low risk when making investment decision .Companies must give up new steel projects which have higher rate of return on investment and lower risk resulting in high opportunity cost.

Finally, debt financing will also bring the potential risk of bankruptcy. Debt financing will increase the risk of bankruptcy and lead to steel companies investing projects with low yield and low risk rather than projects with high yield and high risk.

B. Correlation between control variables and enterprise value

Conclusions below can be draw from the regression analysis of control variables and enterprise value. There is a significant positive correlation between the profitability of listed companies in China's steel industry and enterprise value, which indicates that strong profitability can help companies to increase enterprise value. There is a negative correlation between operating capability and enterprise value, that is to say, companies' operational capabilities to some degree limit the increase of enterprise value, which may be due to the particularity of the steel industry .The real reason remains to be further explored. The control variables business growth has not passed significant test probably because the sample size is still relatively small and cannot accurately reveal the relationship between business growth and enterprise. Of course, it is likely that the business growth does not affect enterprise value as for steel industry.

\section{References}

[1] Modigliani. F and Miller. M, Corporate Income Taxes and the Cost of Capital: A Correction, American Economic Review, vol. 53.pp. 433-443, 1963

[2] Harris, M., and Raviv, A. The Theory of Capital Structure. Journal of Finance. Vol. 6.pp. 297-355, 1991

[3] Titman, S. and R, Wessels, the Determinants of Capital Structure Choice. Journal of Finance. Vol. 43. pp. 109-120,1988

[4] Leland, Hayne and David Pyle, Information Asymmetries: Financial Structure and Financial Intermediation. Journal of Finance, vol. 144. pp. 371-388,1973

[5] Masulis, Ronald. W, The Impact of Capital Structure on firm Value: Some Estimates. The Journal of Finance, vol. 138.pp.107-126, 1983 